consistent with the purpose of the Securities Act, it cannot be taken as a solution of all employee-offering problems which may arise. An area in which the effect of the entire complex of facts is all-important can scarcely be susceptible to comprehensive self-executing regulation. Desirable as certainty may be, each case will in large measure create its own rule, with the over-all purpose of the Act as the principal guide.

\title{
SUPERVISION OF CHARITABLE TRUSTS
}

In 1943, New Hampshire became the first state to establish a comprehensive system for the enforcement and supervision of charitable trusts. ${ }^{1}$ Through enforcement of the donor's intent, mismanagement of trusts has been corrected, and several millions of dollars in previously dormant trust funds have been put to use for the benefit of the state's inhabitants. ${ }^{2}$ The present inquiry will be directed to an examination of the reasons why similar legislation should be adopted by other states; ${ }^{3}$ it will also make definite suggestions regarding the type of "Model Supervision of Charitable Trusts Act" which should be offered to the states by the Uniform Law Commissioners. ${ }^{4}$

A charitable trust is a fiduciary relationship created by the expression of a charitable intent in a will, indenture, or corporate charter. This relationship is present whether the charity is large or small ${ }^{5}$ and whether the class of persons benefited is broad or narrow. ${ }^{6} \mathrm{It}$ is essential that every state provide some system for supervising trustees because the nature of charitable trusts creates a special handicap to the enforcement of the charitable purpose stated in the creating instrument. Normally enforcement of the civil law is predicated on the assumption that when a breach of a legal obligation occurs, the injured party, motivated by his own self-interest, will inform the court of the breach and de-

1 N.H. Rev. Laws 1943, c. 24, \& 13a-13n.

${ }^{2}$ Letter from N.H. Dir. of Char. Trusts (March 25, 1953). This letter and others cited hereafter were received in reply to questionnaires sent to the Attorneys General of states which had provided or were about to provide comprehensive reform, as well as to the "partial reform" states. This material and all legislative and executive papers are on file at the Council of State Governments (Project File: Charitable Trusts, 1953), 1313 E. 60th St., Chicago, Ill.

${ }^{3}$ R.I. Pub. Laws, c. 2617 (1950) established a similar system of state supervision for Rhode Island.

1 On August 8, 1953, the National Association of Attorneys General requested the Uniform Law Commissioners to suggest state legislation concerning regulation of charitable trusts. Alternative preliminary drafts were submitted to the National Association, and on December 10,1952 , that group resolved that the development of alternative "Uniform Acts" which provide for either permissive or mandatory regulation "would enable the states to select the form which best meets their individual needs and requirements." Proceedings of the Conference of the National Association of Attomeys General 155 (1952).

s 3 Scott, Trusts $\$ 375.1$ (1939).

Ibid., at \$375.2. 
mand its correction. But enforcement of the law of charities is made difficult because courts cannot depend upon a self-interested individual to report breaches of trust, for charitable beneficiaries are always indefinite, ${ }^{7}$ usually very numerous and scattered, and often the recipients of very small individual benefits. Moreover, the charitable trustee is not obligated to benefit any single member . of the class of indefinite beneficiaries named in the trust instrument, so the individual beneficiary has no legal "right" to receive the gift. The only persons harmed by the inaction or defalcation of the trustee are the beneficiaries. If they have no standing in court to sue, ${ }^{8}$ the courts are without a "fact-finding" and "suit-bringing" party who will supervise and enforce the execution of the fiduciary duty.

Even if the Attorney General or some other officer were empowered to bring suit when asked, the obstacle of an imperfect fact-finding procedure would still remain. Most beneficiaries would not even know they were harmed because they lack knowledge of either (1) the existence of the trust, (2) the fact that they were intended beneficiaries, (3) the fact that they were probable recipients of the benefits, or (4) the investments, expenses or internal management of the charity. Even if the beneficiaries themselves were given standing to sue, many breaches of fiduciary duty would still go undiscovered, not only because the beneficiaries lack such knowledge, but because they lack the necessary pecuniary interest as well. ${ }^{9}$

Ultimately then, any system of law which purports to enforce charitable trusts must provide some method for overcoming the natural handicaps to enforcement. The systems devised under Roman and British law provide useful examples of procedures which can supply effective supervision.

The Romans had a comprehensive system of enforcement which centered the responsibility for the supervision of trustees in the bishop of the local church.10 He superintended their management and was required "to have a watchful eye over them to remove those who were negligent, and in such cases to appoint other trustees who had the true fear of God in their hearts." "The bishop, in turn, was made responsible to the archbishop or the Province; and the whole hierarchy was reviewable by the people, for every citizen was empowered to make a judicial complaint that the testator's intention was not fulfilled. The

${ }^{7}$ Ibid., at $\$ 364$.

8 Averill v. Lewis, 106 Conn. 582, 138 Atl. 815 (1927); Association For Relief R.A.I.F. v. Beekman, 21 Barb. (N.Y.) 565 (1854), and cases cited 62 A.L.R. 881, 883, 124 A.L.R. 1237, 1238. However, a beneficiary who has a special interest in the performance of a charitable trust can maintain a suit for its enforcement. Canon v. Stephens, 18 Del. Ch. 276, 159 Atl. 234 (1932). In either case, the Attormey General is usually a necessary party to the action. Strickland v. Weldon, 28 Ch. Div. 426 (1885); Larkin v. Wikoff, 75 N.J. Eq. 462,72 Atl. 98 (1909).

'Often, beneficiaries are "poor" or "needy," but even if they can find money to sue, the cost of a lawsuit is often more than the tiny benefit which the plaintiff may receive if the court corrects a breach of trust.

${ }^{10} 10$ Am. L. Reg. 135 (1862).

"Thid., at 136. 
bishop was then warned that by his negligence, he not only would risk the punishment of Heaven, but would suffer from the wrath of the Emperor as well..$^{12}$ Thus the Roman system gave to a local official, who was probably already acquainted with the general facts, the power of investigating and regulating the management of charities. It further provided several checks on the bishop and, through the citizen's complaint, supplemented his investigations.

British attempts to overcome the internal handicaps to enforcement fall into three periods. Before 1601 , the Chancellor's equity powers were available to enforce charitable uses, and the Attorney General, representing the interests of the community, could bring suits "on information" to enforce them..$^{13}$ This enforcement was sporadic, however, and many abuses of trust were not discovered.14

During the period from 1601 to 1853 , attempts were made to "patch up" the law by the enactment of remedial statutes. The famous Statute of Charitable $U_{\text {ses }}{ }^{15}$ gave the Chancellor power to appoint commissioners who would inquire into and correct abuses of trust. The commission system, however, was unsystematic, cumbersome and expensive and in 1812, two new attempts were made to patch up the old law. One act tried to put the public in the investigatory position by providing for summary procedure if two individuals petitioned in the Chancery Court with the approval of the Attorney-or Solicitor-General; ${ }^{16}$ the other act required registration of all charities in a county office. ${ }^{17}$ Such registration might have provided a means for systematic "fact-finding," but apparently it was not generally observed..$^{18}$

The inadequacy of these partial reforms is shown by the fact that when Parliament appointed a commission in 1818 to inquire into the administration of charities, the confusion was so great that it took them 19 years and 37 volumes to make their report. ${ }^{19}$

Finally, in 1853, a comprehensive Charitable Trusts Act was passed in which a Board of Charity Commissioners was set up to supervise and enforce charitable trusts. ${ }^{20}$ Since then, numerous modifications and amendments have been

12 Ibid. Where funds were given for the redemption of Roman captives, the bishop had to notify the Governor of the Province in writing at the time the funds were received; after one year, the bishop was required to report the number of captives redeemed and the amount paid for them. Ibid., at 135-36.

133 Scott, Trusts 1922, 2052 (1939).

14 The very title of the remedial statute enacted in 1601 was "An Act to Redress the Misemployment of Lands, Goods, and Stocks of Money Heretofore Given to Certain Charitable Uses."

1543 Eliz. I, c. 4 (1601).

${ }^{16}$ Charities Procedure Act, 1812, 52 Geo. III, c. 101.

${ }^{17}$ Charitable Donations Registration Act, 1812, 52 Geo. III, c. 102.

184 Halsbury's Encyclopedia of the Laws of England 244-45 (1939).

${ }^{19} 3$ Scott, Trusts 1923 (1939).

${ }^{20}$ Charitable Trusts Act, 1853, 15 and 16 Vict., c. 137. 
made, most of them being consolidated in the Charitable Trusts Acts of 1925.21 The board has both administrative and judicial powers. It may demand accounts, supervise administration, establish schemes, and punish for contempt. It exercises the power of Chancery where the annual income of the charity is less than $£ 50$ or where trustees apply for aid, but its primary use of these powers is in noncontentious cases, for the important disputes are to be left to the courts. ${ }^{22}$ As a result of this comprehensive plan, England now reports very little mismanagement in charitable trusts. ${ }^{23}$

\section{II}

In America, the states have generally failed to provide a good substitute for the lack of a "party-plaintiff" to discover the facts and call on the court to remedy the trustee's failures. Most states still adhere to common law methods of enforcement similar to those used in England before 1601. Others have attempted partial reform, and a third group is composed of the two states which have a comprehensive plan for the supervision of charitable trusts.

Although the states initially adopted the "applicable" parts of the English Common Law system, the American problem was complicated by the absence of the prerogatives of the King. ${ }^{24}$ Under the English common law most of the King's powers and many of the fact-finding duties that pertained to the enforcement of charitable trusts were centered in the Chancellor. He acted as personal delegate of the Crown in exercising the power to appoint commissioners to investigate charities. Where money was given to trustees and no definite charitable objects were specified, ${ }^{25}$ the Chancellor, acting for the Crown, executed the trust under a scheme and cared for the administration of the charity. ${ }^{26}$ In addition, he exercised his normal function of hearing all the controversies which involved these trusts whether they directly concerned enforcement of a fiduciary obligation or not. ${ }^{27} \mathrm{He}$ was, therefore, often in contact with many of these trusts and although neither he nor the Attorney General received reports from the trustees, the Chancellor was in a position to appoint commissioners whenever a matter appeared directly or collaterally that needed investigation. The primary role of the Attorney General was to represent the charitable trust in the argument of cases. Although the Chancellor could begin an action through the commission system without the aid of the Attorney General, it was often more convenient to ask that officer to bring the suit "on information." "28 Thus,

2115 and $16 \mathrm{Geo}$. V, c. 27 (1925).

22 Bogert, Trusts and Trustees 1018 (1935).

23215 L.T. 32 (Jan. 16, 1953).

${ }^{24}$ Fowler, Law of Charitable Uses, Trusts and Donations in New York 43, 47 (1896). Many of the functions of the King were "inapplicable" to American conditions. Ibid., at 48.

${ }^{25} 3$ Story, Equity \& 1581, 1583 (Lyon's ed., 1918).

25 Ibid., at \& 1583. ${ }^{27}$ Ibid., at $\$ 1582$.

${ }^{28}$ Fowler, op. cit. supra note 24, at 36. In Bailiff's of Burford v. Lenthall, 2 Atk. 552 (1743), it was pointed out that when the court was reviewing matters brought before commissioners, 
although the name "Attorney General" appeared in numerous cases, it is very probable that the real "fact-finder" was a commission; an interested party or the Chancellor himself.

The American chancellor did not possess the special powers granted by the King and could not begin an action by appointing commissioners even if a breach of trust appeared collaterally and needed prompt attention. ${ }^{29}$ Thus the heart of the English enforcement system was absent, and the Attorney General came to be regarded as the "guardian" of public charitable trusts in this country, for he was the only person who could properly start an action.

Before an action could be brought, however, the fact finding process had to uncover its need. The "common law" jurisdictions have assumed that interested parties would notify the Attorney General whenever the facts called for his intervention. However, it has been shown that to expect the beneficiaries of a charitable trust to provide that information is unrealistic, and in fact, such complaints have been either non-existent ${ }^{30}$ or have occurred with great infrequency. ${ }^{31}$ Other sources of information, such as trustee reports, personal investigations by the Attorney General or court supplied memoranda are either unused or barren of results. In the common law states, reports have not been required, and it is unlikely that the trustee would voluntarily notify himself of his own breach of trust. ${ }^{32}$ Investigations have not been conducted, ${ }^{33}$ nor has the

it could put the action in the shape of an original bill in which neither side is bound by what appeared before the commissioners but may set forth new matter if they think proper. "This has made the court all along consider it as an original cause, or otherwise, the court would have known nothing of the merits. Therefore, the court has mixed the jurisdiction of bringing information in the name of the Attorney General, with the jurisdiction given them under the statute and proceed either way, according to their discretion." Instead of wasting time and money by appointing commissioners and then examining the action as an original cause on appeal, the Chancellor found it easier to ask the Attorney General to bring the action in the first place.

${ }^{29}$ Jenkins v. Berry, 119 Ky. 350, 83 S.W. 594 (1904), and 122 Ky. 311, 92 S.W. 10 (1906); State ex rel. Heddens v. Rusk 236 Mo. 201, 139 S.W. 199 (1911) (Chancellor's jurisdiction must be invoked by someone else).

so "There has not even been sporadic action by the Attorney General in Rhode Island," testimony of Attorney General William E. Powers quoted in Report of Special Committee To Study the Laws of This State With Respect To Charitable-Trust-So-Called 7 (1950). In Nevada, there have been no complaints in the last 22 years. Letter from Nev. Att'y Gen. (April 23, 1953).

s1 The American Attorney General's enforcement of charitable trusts is sporadic. 3 Scott, Trusts 2053 (1939). In North Carolina, the Attorney General thinks there have been ten cases in the last ten years. Letter from N.C. Att'y Gen. (March 26, 1953). The number of complaints by citizens or interested parties have been "relatively few" in Texas. Letter from Tex. Ass't Att'y Gen. (April 10, 1953). "From none per year to two or three" complaints were received in Ohio. Letter from Ohio Ass't Att'y Gen. (April 9, 1953). In Indiana, the Attorney General instituted about six cases in the last six years. Letter from Ind. Att'y Gen. (March 31, 1953).

:2 However, several trustees have voluntarily sent copies of their yearly court reports to the Attorney General of Indiana. Letter from Ind. Att'y Gen. (March 31, 1953).

ss The Attorneys General of Ohio, Indiana, Nevada, Wisconsin, Texas, and North Carolina do not inspect or investigate any sort of records but rely for the most part on complaints. 
practice of a liaison between the Attorney General and the courts been developed unofficially. However, a few states have recognized the possible value of such liaison and have passed statutes requiring charitable trusts to report annually to a local court which in turn, would notify the Attorney General when a breach of trust occurred. ${ }^{34}$

Questionnaires were sent to these "partial reform" states to see if they fared better in obtaining the much needed facts about the activities of trustees than the "common law" states which relied entirely on sporadic complaints by interested parties. The reply of North Carolina is revealing. There a trustee is required to file annual reports to the superior court, ${ }^{35}$ but if he fails to do so or if the property is mismanaged through negligence or fraud, it is the duty of the clerk of that court to notify the Attorney General or State Solicitor. The Attorney General then has the duty to bring an action in the name of the state, calling on the trustee to render a full and minute account of his administration of the trust fund..$^{36}$ He may also compel the trustee to apply the income as the trust requires. ${ }^{37}$

Although this statute would seem to supply the need for a fact-finding mechanism necessary for supervision and enforcement, the Hon. Harry McMullan of North Carolina writes:

No notice has ever been given this office by any clerk of the superior court under G.S. 36-20 that any charitable trust is being violated in any county, and no action has ever been brought by the State under authority of that section. I am not informed as to the extent which charitable trusts comply with the provisions of G.S. $36-19$ in the various counties of the State but I am of the opinion that very few reports have been filed as required by this section. ${ }^{38}$

Indiana has an equally comprehensive statute, but the Attorney General writes, "I know of no specific instance in which any proceeding was instituted as a result of information sent by a court." "39

In these two states, as well as others, ${ }^{40}$ reports to be submitted to a local court have failed to provide the Attorney General with the necessary informa-

Letters cited note 31 supra, and letters from Wis. Ass't Att'y Gen. (March 31,1953), and from Nev. Att'y Gen. (April 23, 1953). Massachusetts is exceptional, for there, the Attorney General passes upon all accounts which are filed by trustees before they are approved by the court. Letter from Mass. Ass't Att'y Gen. (May 8, 1953).

${ }^{34}$ Ind. Stat. Ann. \$ 7-714 (Burns, 1933); Mass. Gen. Laws Ann. c. 68 \& 15 (Michie Supp., 1946) (Report to Dep't Pub. Welfare); Nev. Comp. Laws $\$ 7718.21$ (Hillyer Supp., 1945); N.C. Gen. Stat. $\$ 36-19$ (Michie, 1950); Ore. Comp. Laws Ann. \$ 73-101 (1940); Wis. Stat.
$\$ 317.06$ (1945).

${ }^{35}$ N.C. Gen. Stat. \& 36-19 (Michie, 1950).

${ }^{36}$ Ibid., at $\$ 36-20$.

${ }^{38}$ Letter from N.C. Att'y Gen. (March 26, 1953).

${ }^{39}$ Letter from Ind. Att'y Gen. (March 31, 1953).

40 No actions were initiated as a result of court reports in Nevada, two in Wisconsin (1952), "few, if any" in Massachusetts, and none in Ohio or Texas. Letters cited note 33 supra. 
tion. In Rome and England, enforcement was effectuated by providing the enforcing agency with direct information about the activities of trustees. While the former system relied on the local bishop's immediate contact with trustees, the English established a specialized central authority which needed to receive reports from trustees if it was to discover mismanagement. If the American Attorney General is to retain this duty of enforcing charitable trusts, he also should receive direct reports from trustees. Perhaps one reason why the Attorney General has not received information through the courts is that these bodies lack specialized personnel to analyze the reports and investigate questionable matters. Skilled personnel in the office of the Attorney General should be given these duties. Direct reports have already proved their worth in the two states where comprehensive supervision has been established. Rhode Island with less than 500 trusts registered has already closed 35 court cases and had 12 matters pending at the time of its first report; ${ }^{41}$ prior to registration there had been no actions initiated by the Attorney General. ${ }^{42}$ Furthermore, supervision is a constant task, for New Hampshire reported 61 cases adjudicated during the last biennium with nine cases pending. ${ }^{43}$ Although it is impossible to determine how many trusts or breaches of trust actually exist in the "common law" and "partial reform" states, 4 the abundant litigation in the "supervision" states indicates that there may be many latent lawsuits wherever trusts are unsupervised.

\section{III}

Before 1900 , the total value of charitable contributions might not have been large enough to warrant the establishment of specialized enforcement machinery by individual states. But since then, the national wealth has greatly increased, and the charitable instinct has caused wealthy men to become philanthropists. ${ }^{45}$ This instinct has been further stimulated by the imposition of a semi-confiscatory tax structure. Although there are no accurate statistics concerning the present total value of charitable trusts, ${ }^{46}$ a few figures will indicate that the states can no longer regard charitable trusts as a de minimus matter. The combined value of Rhode Island and New Hampshire trusts is over $\$ 136,000,000{ }^{47}$

${ }^{41}$ Report of the Administrator of Charitable Trusts (Jan., 1951-Dec., 1952).

42 Report of Special Committee, op. cit. supra note 30.

43, N.H. Attorney General's Report (1950-52).

${ }_{44}$ The Attorneys General do not even have information about the number of trusts in their state. Letters cited note 33 supra.

${ }^{45}$ Men like Andrew Carnegie believed that the millionaire should be "a trustee for the poor. ... The man who dies ... rich dies disgraced." Carnegie, The Gospel of Wealth 18 (1906). Carnegie donated 200 million dollars and the Rockefellers 700 million dollars to charity even before the period of high taxes.

${ }^{46}$ According to a 1932 survey discussed by Blackwell in "The Charitable Corporation and the Charitable Trust," 24 Wash U.L.Q. 1 (1938), over nine billion dollars in property and endowment were being handled by philanthropy's trustees, but many billions have been given since then.

47 Letter from N.H. Dir. of Char. Trusts (March 25, 1953); Report of the Administrator of Charitable Trusts (Jan., 1951-Dec., 1952) (R.I.). 
In Massachusetts, a survey in 1935 revealed more than 50,000 bequests to charity totaling $\$ 48,000,000$ in one county alone. ${ }^{48}$ On the other hand "foundations," ${ }^{49}$ a type of charity usually in the corporate form, ${ }^{50}$ have a total national value of about two billion dollars. ${ }^{51}$

It seems strange that the states should have neglected their responsibility for supervising the private management of these quasi-public funds, especially when the state and federal governments have so generously subsidized charities by exempting them from taxation. How much of this "public property" has been wasted or diverted as a result of this negligence is a speculative matter, but modern uses of the charitable trust device give some indication of the shocking consequences of "lenient" state enforcement.

Before 1950, the high tax rates, the exception of charitable gifts from taxation, and the "lenient" policy of state supervision over charities combined to make the charitable trust a popular tax-saving device. Numerous articles appeared explaining in detail the advantages of various tax saving schemes such as "giving" to one's own charitable foundation, while at the same time retaining control of the gift. ${ }^{.2}$ The Revenue Act of $1950^{58}$ specifically attacked these schemes by providing for revocation of the tax exemption when charities engaged in such activities. Since a revised system of charitable trust enforcement must operate under continued federal tax regulation, the revision should consider its relationship to the Revenue Act of 1950.

Before the 1950 Act was passed, the charitable trust was used to avoid estate taxes, to reduce yearly income taxes, and to retain and increase capital. In order to keep property in control of the family and avoid the necessity of selling much of the estate to pay taxes, property was donated to a charitable foundation controlled by the testator's family. In this way "white elephants" which were diffcult to sell, works of art, country estates, patents, and closely held stocks and

43 Report and Recommendations for Legislation of Former Attorney General Bushnell, 30 Mass. L.Q. 22, 24 (May, 1945). The Attomey General of Massachusetts estimates that the present value of charitable trusts in the whole state is now about 100 million dollars. Letter from Mass. Att'y Gen. (May 8, 1953).

19 A "foundation" has been described as a non-profit, non-governmental organization having a principal fund of its own, established for charitable, educational, or similar purposes. Eaton, Charitable Foundations, Tax Avoidance, and Business Expediency, 35 Va. L. Rev. 809,987 , at 814 (1949).

so The Modern Philanthropic Foundation: A Critique and a Proposal, 59 Yale L.J. 477, 481 (1950); Clark, How To Get the Most Out of the Deduction for Charitable Contributions by Individuals and Business, 6 N.Y.U. Inst. Fed. Tax 1015 (1948).

s1 Estimated by Sloan Foundation, N.Y. Times, p. 21, col. 1 (Aug. 17, 1949).

52 How to Have Your Own Foundation, 36 Fortune, No. 2, p. 108 (Aug. 1947); Eaton, Charitable Foundations, Tax Avoidance and Business Expediency, 35 Va. L. Rev. 809, 987 (1949); Lasser, How Tax Laws Make Giving to Charity Easy (1948); Clark, How to Get the Most Out of the Deduction for Charitable Contributions by Individuals and Business, 6 N.Y.U. Inst. Fed. Tax 1015 (1948); Harriss, Taxes and Philanthropy, 70 Trusts and Estates 117 (1940).

${ }^{63}$ Pub. L. No. 814, 81st Cong., 2d Sess., approved Sept. 23, 1950. 
investments could be carved out of the estate as exempt charitable gifts and yet remain in the hands of trustees friendly to the family. ${ }^{54}$ This practice had the additional advantage of leaving the estate more liquid than it would have been if such property had to be evaluated and sold for taxes. An extra tax saving would result if appreciated property could be given for it could be exempted from the estate tax at its present value and yet the interim capital gain was not taxable. ${ }^{55}$

Controlled charities had additional advantages in that the income from the donated property might be largely eaten up by "expenses" which served no charitable purpose. Management fees, compensation for services rendered to the charity and the like could easily be paid to relatives, servants, and friends. ${ }^{66}$ In addition, dealings with certain persons or companies may be conducted on very liberal terms, as long as all such expenses and dealings were "reasonable." In fact, even the beneficiaries selected by such a charity could be friends of the donor or trustee, for it was not hard to select a class of beneficiaries so "general" that the trustees or directors could follow the words of the trust and still have considerable discretion as to whom to benefit. ${ }^{57}$ Charities were also used to reduce yearly income taxes during the donor's lifetime. Corporations and individuals could establish a foundation, make year end donations of controllable property, and reduce their net taxable income by $5 \%$ and $15 \%$ respectively. Furthermore, the income from the donated property would be tax free and available for "expenses."

High tax rates had depleted many of the traditional supplies of accumulated capital, so some men who wished to expand their company's activities looked to charitable trusts for the necessary venture capital. ${ }^{58}$ By trading on the charity's tax exemption and allowing its income to accumulate, capital was rapidly created. One scheme was to set up a charity and have the trustees borrow money, buy a factory from the company, lease back the factory, and pay off the loan out of the proceeds from the tax-exempt rentals. ${ }^{59}$ Another method would be to donate stock to the charity and then increase the assets of the charity by high tax-exempt dividends until enough money was accumulated so that the charity could either buy the stock of a competitor and sell it cheaply to the company at any convenient time, or make unsecured or poorly secured loans of capital to the company. ${ }^{60}$ Of course, the company could always sell its assets to the charity at a loss and take a tax deduction; the charity could then sell those assets at a tax-exempt profit and use the proceeds to buy and lease back more company property..$^{61}$ The trustees of such charities were usually exempted from

54 See discussion by Eaton, op. cit. supra note 49, at 836-38, 990-93.

'ss Ibid., at 833, 990.

6s Thid., at 993.

so Ibid., at 1013 et seq.

"7 Ibid., at 994-95.

${ }^{60}$ Ibid., at 1011-1013.

58 Ibid., at 1005, 1022.

61 Ibid., at 1021. 
liability for negligence in those transactions by a specific clause in the trust. ${ }^{62}$ Most of these devices were explored by Royal Little in his fabulous manipulations of Textron, Inc., ${ }^{63}$ and were also used in varying degrees by others including educational institutions and insurance companies. ${ }^{64}$

These tax saving devices were widely criticized as "loopholes" in the tax law. ${ }^{65}$ However, except for the problem of charities trading on their tax exemption by borrowing money for lease-back transactions, most of the difficulties arose because of the "loophole" in the charity law. If trustees had been adequately supervised, unreasonable accumulations and expenses would have been largely prevented, and the use of the corpus and income by the donor instead of the beneficiaries would have been minimized. Since the state did not provide such supervision, however, Congress had no choice but to "rush right in where experts feared to tread" and enact a law which would preserve the policy of encouraging private philanthropy and yet halt the use of charities as tax saving devices. The complicated Revenue Act of 1950 attempted to solve this problem by providing for revocation of the tax exemption whenever charities engaged in the activities which had been subject to abuse. While the details of this Act have been fully criticized and explained elsewhere, ${ }^{66}$ the main question to be considered here is the effect of the Act upon charities and charitable trust enforcement.

One immediate effect of the Act upon charities is that its tax exemption is denied when the trustee, for example "engages in any other transaction which results in a substantial diversion of its income or corpus to; the creator of such an organization (if a trust); a person who has made a substantial contribution. ..."'77 In effect, a new standard for "reasonable management" has been established for trustees, and the tax collector, not the Attorney General, has been given the task of interpreting and "enforcing" that standard. But the "enforcement" weapon prescribed by the Revenue Act not only fails to enforce the charitable intent by punishing trustees for imprudent management, it actually deprives the charity itself of an amount of money equal to the tax exemption because of a trustee's wrongful mismanagement! The 1950 Act may even have discouraged charitable contributions, for there is always the possibility that the wrongful act of a trustee may cause the charity to lose its exemption; in that event, contributions by persons unaware of that fact would be

as Yale L.J., op. cit. supra note 50 at 496.

6z Ibid., at 492-97; see also discussion of Textron activities by Eaton, op. cit. supra note 49, at $1022-1034$.

64 Eaton, op. cit. supra note 49 , at $1000-1002$.

os Ibid., at 1034. Eaton speaks of the study of tax exempt organizations "with an eye to closing some of the loopholes, especially those in 101(6)."

${ }^{86}$ Eaton, Charitable Foundations and Related Matters Under the 1950 Revenue Act, 37 Va. L. Rev. 1, 253 (1951); Colleges, Charities, and the Revenue Act of 1950, 60 Yale L.J. 851 (1951); Hilinski, Some Comments on the Revenue Act of 1950, $99 \mathrm{U}$. of Pa. L. Rev. 455, 610 (1951); Morgan, Present Status of "Exempt" Corporations, 31 Taxes 296 (1953).

${ }^{67}$ Pub. L. No. 814, op. cit. supra note 53, at \& 321(a), adding Int. Rev. Code $\$ 162(\mathrm{~g})(2)(\mathrm{A})$, (B); and § 331, adding Int. Rev. Code $\$ 3813(\mathrm{a})$, (b) (6). 
taxable retroactively. ${ }^{68}$ In short, the 1950 Act punishes charities instead of punishing abuses of trust; it neither encourages private philanthropy nor supervises trustees.

If a state enacted a Model Supervision of Charitable Trust Act, the Attorney General would be able to protect charities from the special interests of donors, trustees and the tax collector. He could insist on prudent management by trustees and prevent them from engaging in activities which would jeopardize the charity's tax exemption. Even though the Revenue Act remained in force to guard against abuses of the federal tax structure, the Attorney General could virtually eliminate the necessity for its use by insuring that the charitable intent is observed in all charitable trusts. ${ }^{69}$ Supervision, therefore, would close most of the loopholes that the tax law was so clumsily trying to correct. Most important of all, it would carry out the policy of encouraging private philanthropy in a straightforward and beneficial manner.

\section{IV}

The urgent need for reform to prevent neglect and abuse of charitable funds is clear. Such reform, if enacted, would benefit business, government, and the charities. Supervision would not prevent charities from supplying capital to business by legitimate investments. However, the use of the charitable device to secure unfair business advantages to the donor, either by his control of the charity or by his trading on its tax exemption, would be discouraged under supervision just as it is under the tax law. Government would benefit directly from private contributions to state owned institutions. ${ }^{70}$ Indirectly, the expense of promoting and maintaining the general welfare would be reduced. By compelling efficient management by trustees, the government would protect the community interest in the benefits from these quasi-public funds and would insure that its own tax exemption "contribution" be used to the utmost advantage. Charity itself, receives the greatest benefits from supervision. The results in New Hampshire are exemplary:

Trust funds which lay dormant for one reason or another came to life again for the benefit of charities... Probate accounts by trustees became more numerous and complete. Some trustees had not reported for periods ranging from five to twenty years. ... Nondistributed funds were turned over to the intended charities, investments became more prudent, with the corpus not speculatively sacrificed to income and vice versa. Stability of investment consistent with reasonable income was the standard laid down for trustees. The charges made for trustees' fees were controlled

${ }^{88}$ Pub. L. No. 814, op. cit. supra note 53, at $\$ 321$ (a), adding Int. Rev. Code $\$ 162(\mathrm{~g})(2)(\mathrm{E})$, (F); and $\S 331$, adding Int. Rev. Code $\S 3813(\mathrm{e})$, (f).

"9ven if the charity had already lost its exemption, the Attorney General, by timely action could make sure that it was immediately reinstated under Pub. L. No. 814, op. cit. supra note 53, at $\S 321(\mathrm{a})$, adding Int. Rev. Code $\S 162(\mathrm{~g})(2)(\mathrm{D})$; and $\S 331$, adding Int. Rev. Code $\$ 3813$ (d).

${ }^{70}$ In New Hampshire, a $\$ 38,000$ gift to the state hospital was assured because of alert supervision in that state. N.H. Attorney General's Report (1946-48). 
so that trust funds might not be exploited for personal gain and to the detriment of the charities involved. In one case, the trustees were taking an unreasonable per cent of the annual income for fees in disregard of a specific provision in the will allowing much less for their services. The bad practice of accumulating a large portion of the income each year was stopped. In one case income was accumulated in the sum of $\$ 100,000$ over a period of eighteen years. . . . Petitions for $c y$ pres application of funds left for objects no longer practicable were also more frequent. In one case a fund of nearly a million dollars, with only two years to go before a testamentary limitation of twenty years would have become effective, with resulting reversion to the estate, was awakened and immediate steps were taken to prevent forfeiture and to insure its application for the benefit of the inhabitants of New Hampshire in the field of education. ${ }^{\pi}$

The biennial reports of the New Hampshire supervision department are replete with other examples of the stimulation of charities. ${ }^{72}$ In the long run, supervision undoubtedly would encourage more gifts to charity, for donors would be assured that the money they give would reach the intended beneficiaries. ${ }^{73}$

Some of the major objections to comprehensive supervision were expressed when Massachusetts considered its adoption in 1945. ${ }^{74}$ The Judicial Council was requested to investigate its desirability ${ }^{76}$ and in arguing against supervision said that the proposed Division of Public Charities would be a "new 'bureau' of enormous size and scope of authorized activities, capable of practical expansion of assumed power with all the possible, conceivable, and proverbial insolence of office which the imagination of some future officials in the department might suggest." When government acts to promote the general welfare, bureaucratic size and insolence are possible. It is the possibility of such defects arising from the machinery of particular legislation which must be weighed against the results it is expected to achieve. The size of the "bureaucracy" in New Hampshire is a part-time director and a registrar ${ }^{77}$ in Rhode Island, only three persons are employed in its Division. ${ }^{78} \mathrm{New}$ Hampshire reports that its policy of friendly supervision is well received by all, including donors, trustees, and beneficiaries. ${ }^{79}$

Secondly, it was argued that supervision would increase state expenses. ${ }^{80}$ There will, of course, be some expense involved in supervision. New Hampshire supervises a trust corpus of 75 million dollars at a cost of $\$ 8,610$ per year. ${ }^{81}$ It

71 N.H. Attorney General's Report (1944-46).

72 E.g., a school plan was adopted so that $\$ 750,000$ in trust funds could be put to work after they had accumulated for 25 years. N.H. Attorney General's Report (1946-48). Under the present tax law, the fund might have been taxed instead of simulated!

${ }^{73}$ N.H. Attorney General's Report (1946-48).

74 Report and Recommendations for Legislation of Former Attorney General Bushnell, 30 Mass. L.Q. 22 (May, 1945).

${ }^{75}$ Judicial Council, Discussion of Recommendations, 30 Mass. L.Q. 42, 45 (Dec., 1945).

${ }^{76}$ Ibid., at 46. $\quad{ }^{77}$ Letter from N.H. Dir. of Char. Trusts (March 25, 1953).

${ }^{78}$ Letter from R.I. Admin. of Char. Trusts (March 24, 1953).

79 N.H. Attorney General's Report (1950-52). $\quad{ }^{80}$ Mass. L.Q., op. cit. supra note 75, at 47.

${ }^{81}$ Letter cited note 77 supra. In Rhode Island, it costs $\$ 14,000$ to supervise a trust corpus of 61 million dollars. Letter cited note 78 supra. 
is also costly for a state to allow public funds to be wasted or unused. "In 1946 and 1947, steps were taken to obtain the required trustee's reports in the Elisha Munsell Trust and as a result the prompt payment of $\$ 38,000$ to the State Hospital was assured." 82 This one private gift paid the expense of over four years of supervision. Larger states might prefer a plan proposed for Texas whereby the cost is partially defrayed by percentage registration and filing fees from the trusts themselves. ${ }^{83}$ The savings from supervision are cumulative ${ }^{84}$ and continuous. After almost ten years of supervision, New Hampshire reports, "Dormant funds still come up for attention." 85

It was also said that, sooner or later, any issue requiring the representation of the Attorney General will come to his attention either by a complaint of interested parties, a petition for instructions, an application of $c y$ pres, or some other means. ${ }^{86}$ It has already been shown that in most states, complaints do not reach the Attorney General..$^{87}$ In many instances, the delay may cause a complete loss of property because of a reverter or through negligence.

Next it was urged that because some trusts need attention there is no reason why the others "should be subjected to this interminable, and very probably in the future, intolerable interference and burden of reports and inquisitions." ${ }^{28}$ Supervision would involve some additional expense to each charity. However, since adequate records are indispensible to a well managed charity, the required annual reports ordinarily would involve a mere transfer of information to a form supplied by the Attorney General. Moreover, states already requiring reports to a court could standardize the two forms, so that duplicate reports could be filed with almost no additional cost. Since the proposal Act would give the Attorney General no right to interfere with lawful management, "inquisitions" would be in order only should the reports indicate the need.

Finally, the Council pointed out that the English comprehensive supervison statute includes powers of changing the management of the trust in ways which would be unconstitutional in Massachusetts. "The fact of these arrangements in England do not persuade us that a similar centralized establishment should be adopted here where conditions differ as well as history." 89

It is true that the English application of $c y$ pres and other equity powers is much broader than the more limited use they receive in America. However, a Model Supervision of Charitable Trusts Act would not change the existing substantive law of charities in any given state. The courts would still decide whether to punish the trustee, change the management or dismiss the suit.

N.H. Attorney General's Report (1946-48).

${ }^{8 s}$ Texas H.B. No. 538, $\$ \$ 10,15$ (1953).

84 Property that is quickly recovered from loss through mismanagement will increase total income over a period of years.

${ }^{85}$ N.H. Attorney General's Report (1950-52).

${ }_{88}$ Mass. L.Q., op. cit. supra note 75, at 51 .

${ }^{87}$ See material cited note 31.

${ }^{88}$ Mass. L.Q., op. cit. supra note 75, at 46.

${ }^{89}$ Ibid., at 52. 
Even the Attorney General's duty of investigating and suing to correct breaches of trust would remain essentially unchanged. The main purpose of the Act would be to provide adequate machinery for the execution of those duties. The success of the English system of centralized reporting ${ }^{90}$ would seem to be a reason for adopting, not rejecting similar reforms in this country.

It can be seen that these several objections constitute no great obstacle to the establishment of supervision. It might also be argued, however, that the existing criminal laws relating to embezzlement or tax evasion are adequate to punish breaches of trust. But the report of New Hampshire that "loose and distracted administration was found in about $25 \%$ of the cases,"91 suggests that the presently existing law is not an adequate safeguard against mismanagement.

$\mathrm{V}$

In drafting a Uniform Supervision of Charitable Trusts Act, the followng problems must be considered: 1) Is there a need for uniformity? 2) Should all charitable trustees be subject to supervision? 3) What specific provisions are necessary to enable the Attorney General to carry out his "fact-finding" and "suit-bringing" duties?

Uniform state legislation has been valuable in the fields of banking and commerce. In these areas a person frequently may be subject to the laws of several different states in the same type of transaction, thus making detailed uniformity desirable. However, the problem of supervision of charities is more like the regulation of corporations in which the laws of only one state are applicable. Uniform corporation registration is desirable because of the possibility that the corporation will shift its registration to the state with the most lenient rules. However, if a charity is required to register in the state where most of its property is located, the possibility of shifting to states with less supervision is almost eliminated. In fact, even as to charities which could change the situs of their property, the value of uniformity could be achieved only if there were substantially identical supervision in all the states, a nearly impossible goal. Furthermore, the provisions of a Uniform Act would have to be "watered down" so that they would be acceptable to every state, regardless of its size, constitution, number of trusts, or internal administrative framework. The very fact that a "permissive" Act has been drafted which provides that the Attorney General "may" require trustees to file reports and that trustees shall file copies of the creating instrument "if" requested to do $\mathrm{s}^{92}$ shows the extent to which a Uniform Act might become a mere gesture if its main object was to establish identical practices in all 48 states. Those states which wanted to establish really effective enforcement might even be held back by a "watered down" Uniform Act. What is needed is not uniformity, but effective supervision regardless of the form of the machinery, in all states.

\footnotetext{
${ }^{90} 215$ L.T. 32 (Jan. 16. 1953).

\$2 $\$ 2$ of the "permissive" Act. See note 4, supra.

${ }^{91}$ N.H. Attorney General's Report (1942-44).
} 
On the other hand, the draftsmen of a "Model Act" could ignore the peculiarities of individual states and construct a statute which would be a "model" of the best method for supervising charities. Then, if the legislature of a given state felt compelled to eliminate certain parts of the Act, the omissions or exceptions would plainly indicate the extent to which that state was depriving itself of effective, comprehensive and money saving enforcement. Actually, some flexibility is desirable to allow new provisions to be incorporated after supervision has been established. This allows for experimentation with new methods and permits the elimination of sections which are of doubtful value for a given state.

The scope of the "Model Act" must include all forms and types of charitable trusts, and the criterion for requiring trustees to register should be the Common Law test of whether the intent of the donor was "charitable." The tentative draft of the "mandatory" Uniform Supervision of Charitable Trusts Act excepts religious or educational corporations holding funds or property in trust exclusively for their own charter or corporate purposes ${ }^{93}$ from the duty of reporting. Thus, when a corporation is formed for the purpose of providing scholarships for needy students or when the charter purpose is to erect and maintain a church, the persons who administer the funds are excused from supervision, but if the same purpose is manifested in a will or indenture creating a trust, the trustees must report to the Attorney General. This purely formal distinction does not seem to serve any useful purpose, and the exception should be dropped, for a donor's decision as to whether he should use one legal form or another should not be determined by his desire to have, or not to have supervision. If the arguments concerning recovery of dormant funds, enforcement of a fiduciary obligation, and protection of the government's tax-exemption subsidy to charities have any validity, they are as applicable to one legal form as to another. For this reason, inter vivos and testamentary trusts, charitable corporations, and all forms of charitable future interests should be supervised. Although the tentative draft of the Uniform Act seems to include the first three forms in its definition of "charitable trust," ests in favor of charities are meant to be included. The "charitable trust" must "subject the person by whom the property is held to equitable duties to deal with the property for a charitable purpose." If a trustee were given property and required to pay the annual income to a widow and after her death to charity, he would be dealing with the property for private purposes until the widow's death. If he were not required to account, it would be very possible for the widow to prevail upon the trustee for part of the corpus, until it has disappeared, before the charity has enjoyed it. The words "to be enjoyed either now or at some time

${ }_{93}$ Uniform Supervision of Charitable Trusts Act \& 1, Handbook of the National Conference of Commissioners on Uniform State Laws 515-18 (1952).

94 "Charitable trust" means a fiduciary relationship with respect to property arising as a result of a manifestation of an intention to create it, and subjecting the person by whom the property is held to equitable duties to deal with the property for a charitable purpose. Ibid. 
in the future" could be added at the end of the definition of "charitable trust" to preclude a narrow interpretation of "to deal."

At this point, the Model Act provides for the supervision of all charities, regardless of their legal form. However, some people will undoubtedly insist that this or that type of school, church, or Ford Foundation should be specially exempted from making reports. The churches might claim constitutional immunity, and the schools that they are already supervised by the state. The difficult task of defining which charities have an adequate excuse for not making reports to the Attorney General should be left to the individual states. Generally, though, the fact that the Attorney General has always been a proper party to enforce religious and educational trusts, ${ }^{95}$ and the fact that the taxpayers are granting these large charities a substantial exemption-subsidy on the assumption that they are pro bono publico seem to indicate that there is no reason why the community should not at least be entitled to a report of the bono publico. Only when some other supervision equals the standards of the general charitable supervision should organizations be exempted from the coverage of the Act.

The implementation of the Act is the one remaining problem to be discussed. The tentative draft of the "mandatory" Uniform Act already includes some of the basic provisions that should appear in a "Model Act." Section Two provides that every trustee shall file a copy of the instrument creating the trust with the Attorney General, and Section Three requires the trustee to render an annual report to that officer. These are the all-important fact-finding sections. Other provisions give the Attorney General power to make rules and regulations, ${ }^{96}$ to establish and maintain a record of reports, ${ }^{97}$ and to allow inspection of the records at reasonable times and for legitimate purposes. ${ }^{98}$

Besides these basic sections, there are others that should be added in order to keep the Attorney General informed about litigation which occurs "between reports."

A section that is being presented for the first time in the Texas and Ohio bills is the provision that the Attorney General must be a necessary party to and must be notified of all judicial proceedings affecting a charitable trust within the state. "A judgment rendered in such proceedings without service of citation upon the Attorney General shall be void, unenforceable, and subject to collateral attack." 99 This is an excellent way of insuring that the Attorney General is informed about litigation which could harm a trust before he can take steps to protect the charitable interest. ${ }^{100}$

${ }^{95}$ E.g., State ex rel. Att'y Gen. v. Van Buren School District, 191 Ark. 1096, 89 SW. 2d 605 (1936), and cases cited in 62 A.L.R. 881, 883 n. 8.

${ }^{98}$ Handbook, op. cit. supra note 93, at $\$ 4$.

${ }^{97}$ Tbid., at $\$ 7$.

${ }^{98}$ Ibid., at $\S 8$.

${ }^{29}$ Tex. H.B. No. 538, $\S 4$ (1953); $\S 109.25$ of the proposed Ohio Act.

${ }^{100}$ The Attorney General of Ohio in a speech recommending supervision, said, "The whole purpose of the trust may be changed by application of the cy pres doctrine, and there is no provision for the representative of the public to be heard. A short time ago an attorney ap- 
The requirement that the Attorney General be informed and made a party does not, however, preclude the possibility of his granting leave to interested parties to conduct the suit by using their own counsel. As a matter of fact, where state funds are limited and where the number of beneficiaries is rather small, it might save money to allow such a practice. The Attorney General could even notify interested parties of a breach of trust and suggest that they bring the suit with his approval, but with the proviso that he must accept the judgment before it is valid against the charity so that he reserves the right of appeal. He should, of course, retain his duty to bring suit if the interested parties refuse or later withdraw.

The Texas and Ohio bills contain a provision for notifying the Attorney General when any will that contains clauses creating a charitable trust is brought to the probate court; no compromise, settlement, agreement or judgment which modifies or terminates the charitable trust is valid unless the Attorney General is a party thereto, nor may the trust be modified or terminated by decree of the probate court unless the Attorney General is given an opportunity to be heard. ${ }^{101}$ The Model Act should certainly include such a provision, since it is the only effective way of preventing a settlement detrimental to the charitable purpose and assuring that the court is reminded-in this case by arguments presented by the Attorney General - that cy pres may very well be applied in order to save the gift for charity.

Besides the provisions for gathering information, the Model Act should include a section which states "regardless of any language in the agreement, deed, or other instrument creating a charitable trust, no trustee or trustees shall be exonerated from liability for failure to exercise reasonable care, diligence and prudence. ${ }^{\prime 102}$ A section of this sort is needed to prevent men like Royal Little from including exoneration clauses in the creating instrument. Little used such clauses to protect his "controlled" trustees from liability for making huge investments in his companies and performing all the other ingenious feats that he planned. This kind of exoneration is certainly to be discouraged, for if a trustee is penalized for such actions, the Attorney General has one more device by which he can "encourage" trustees to do their job and do it well.

proached our office seeking our reaction to a substantial change in the purpose of a large trust. Upon learning that we would take an active interest in the matter, he left and we heard no more until we read in the papers that the matter had proceeded to a hearing and the change accomplished. Shortly thereafter, upon discovering that some real estate was involved we were peremptorily presented with an entry and asked to approve." That situation could never occur with the "necessary party" provision, or if it did, the judgment would be void. Address by C. William O'Neill, Att'y Gen., to Montgomery Co. Bar Ass'n.

$101 \S 109.29$ of the proposed Ohio Act, and Texas H.B. No. 538, $\$ 6$ (1953).

103 Tex. H.B. No. 538, $\$ 17$ (1953). A similar provision is used in R.I. Pub. Laws (1950) c. $2617, \S 13$. 